\title{
月経時に腸閉塞を繰り返した回腸子宮内膜症の一例
}

豊橋市民病院 産婦人科 ${ }^{1}$ 、同 女性内視鏡外科 ${ }^{2)}$ 、同 総合生殖医療センター ${ }^{3)}$ 池田芳紀 ${ }^{1)}$ 、梅村康太 ${ }^{2}$ 、植草良輔 ${ }^{1)}$ 、國島温志 ${ }^{1)}$ 、松尾聖子 ${ }^{1)}$ 、甲木 聡1)

藤田 啓 ${ }^{1)}$ 、矢吹淳司 ${ }^{1)}$ 、北見和久 ${ }^{1)}$ 、吉田光紗 ${ }^{1)}$ 、河合要 介 $^{1)}$ 、 高野みずき ${ }^{1)}$ 、岡田真由美 ${ }^{1)}$ 、安藤寿夫 ${ }^{3)}$ 、河井通泰 ${ }^{1)}$

\section{Ileal endometriosis with a recurrence of intestinal obstruction during menstruation}

\author{
Yoshiki Ikeda $^{1)}$, Kota Umemura ${ }^{2)}$, Ryosuke Uekusa ${ }^{1)}$, Atsushi Kunishima ${ }^{1)}$, Seiko Matsuo ${ }^{1)}$, \\ Satoru Katsuki ${ }^{1)}$, Kei Fujita ${ }^{1)}$, Atsushi Yabuki ${ }^{1}$, Kazuhisa Kitami ${ }^{1)}$, Misa Yoshida ${ }^{1)}$, \\ Yosuke Kawai $^{1)}$, Mizuki Takano ${ }^{1)}$, Mayumi Okada ${ }^{1)}$, Hisao Ando ${ }^{3)}$, Michiyasu Kawai ${ }^{1)}$ \\ Department of Obstetrics and Gynecology, Toyohashi Municipal Hospital ${ }^{1}$, \\ Department of Female Endoscopic Surgery, Toyohashi Municipal Hospital ${ }^{2}$, \\ Center for Reproductive Medicine and Surgery, Toyohashi Municipal Hospital ${ }^{3)}$
}

\begin{abstract}
Bowel endometriosis sometimes causes repeated intestinal obstruction during menstruation. Recently, there are an increasing number of cases of bowel endometriosis treated with laparoscopic bowel resection. We had a case of ileal endometriosis with recurrence of intestinal obstruction during menstruation. A 34 year-old woman was referred with a left ovarian endometrioma $4 \mathrm{~cm}$ in diameter. She had just recovered from conservative treatment of intestinal obstruction, which had developed during menstruation. We planned a laparoscopic cystectomy of her left ovarian endometrioma. She relapsed with intestinal obstruction during menstruation, which was again treated conservatively. Computed tomography at the onset of intestinal obstruction showed stenosis of the distal ileum. Ileal endometriosis was suspected as the cause of this stenosis. Her next menstrual period was estimated to overlap with the planned laparoscopic operation. Another recurrence of intestinal obstruction during her next menstruation could necessitate a delay in the operation, or a conversion to laparotomy. She was treated with dienogest for prevention of intestinal obstruction recurrence for one month before the operation. Concurrent laparoscopic resection of the left ovarian endometrioma and ileal endometriosis was performed as scheduled without recurrence of intestinal obstruction. Pathological examination confirmed ileal endometriosis and left ovarian endometrioma. No recurrence of either ovarian endometrioma or intestinal obstruction has been detected for one year after the operation. Our experience suggests that it would be better to avoid planning laparoscopic surgery during menstruation in suspected bowel endometriosis, or to start drug treatment to prevent endometriosis-associated bowel obstruction.
\end{abstract}

Key words: ileal endometriosis, intestinal obstruction, laparoscopic surgery

\section{【緒 言】}

腸管子宮内膜症には特異的な診察所見や画像所 見はなく、初期には無症状であるため診断が難し い。しかし、進行すると月経に随伴する消化器症 状や腸閉塞を認めるようになる。近年では腸管切 除などの外科的治療を腹腔鏡下で行うことが多く
なってきている。今回我々は、月経時に腸閉塞を 繰り返し、腸閉塞発症時のCT所見により回腸子 宮内膜症の存在を術前に疑って、外科との連携の もと腹腔鏡下で一期的に左卵巣子宮内膜症性囊胞 とともに切除しえた症例を経験した。腸管子宮内 膜症が疑われる際に腹腔鏡下手術を計画する上で 留意すべき点につき知見を得たので報告する。 


\section{【症例】}

患者：34歳女性、0 経妊、身長162 cm、体重44.6 $\mathrm{kg} 、$ BMI $17.0 \mathrm{~kg} / \mathrm{m}^{2}$

既往歴：原発性不妊症（不妊期間 5 年、 4 年前に 他院で一般不妊治療)、月経困難症

主訴：月経時の腹痛・嘔吐

現病歴：月経発来とともに初めて上記症状を認め たため、近医を受診した。腸閉塞の診断で保存的 治療を受けた。月経 2 日目に撮影されたMRIで 4 $\mathrm{cm}$ 大の左卵巣子宮内膜症性囊胞が疑われたため、 当院に紹介された。

血液検查所見:CA125 $141.1 \mathrm{U} / \mathrm{mL}$ (月経11日目)、 CA19-9 97.2 U/mL（月経11日目)、 AMH $3.73 \mathrm{ng} /$ $\mathrm{mL}$

画像検査所見:月経30日目の骨盤部MRI（図 $1 \mathrm{a}$, b ）ではT1強調画像で高信号、T2強調画像で低 信号の $4 \mathrm{~cm}$ 大の囊胞性病変を左卵巣に認め、子
宮内膜症性囊胞と診断した。撮像範囲内の腸管に は腫瘤性病変を指摘できなかった。月経34日目の 腹部CT（図 $2 \mathrm{a}, \mathrm{b}$ ) では腸管の拡張や液体貯 留を認めず、腸管に腫瘤性病変を指摘できなかっ た。月経16日目に施行された下部消化管内視鏡検 査では異常所見を認めなかった。

経過：画像検查上は腸管子宮内膜症の存在は明ら かではなかったが、月経随伴性に腸閉塞を発症し たエピソードから腸管子宮内膜症の関与を疑っ た。挙児希望があり他院でタイミング法や人工授 精を経験したが妊娠に至らなかったこと、月経時 には鎮痛薬内服が久かせないほどの月経困難症も あったこと、これらから腹腔鏡検査も兼ねて左卵 单子宮内膜症性囊胞に対し腹腔鏡下囊胞摘出術を 予定した。

腸閉塞治療後 2 周期目の月経発来とともに腸閉 塞が再発したため、保存的に治療した。腸閉塞発 症時のCT（月経 2 日目に撮影）では、小腸の著

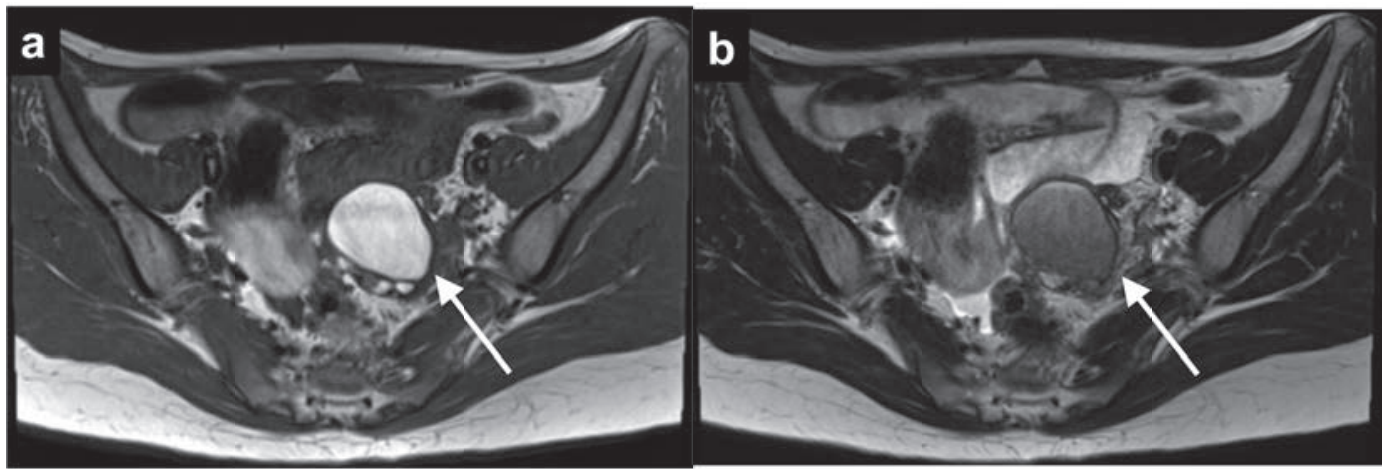

図1月経30日目の骨盤部MRI（a：T1強調画像、 b : T2強調画像） 左卵巣に $4 \mathrm{~cm}$ 大の囊胞性病変を認め、子宮内膜症性囊胞と診断した。
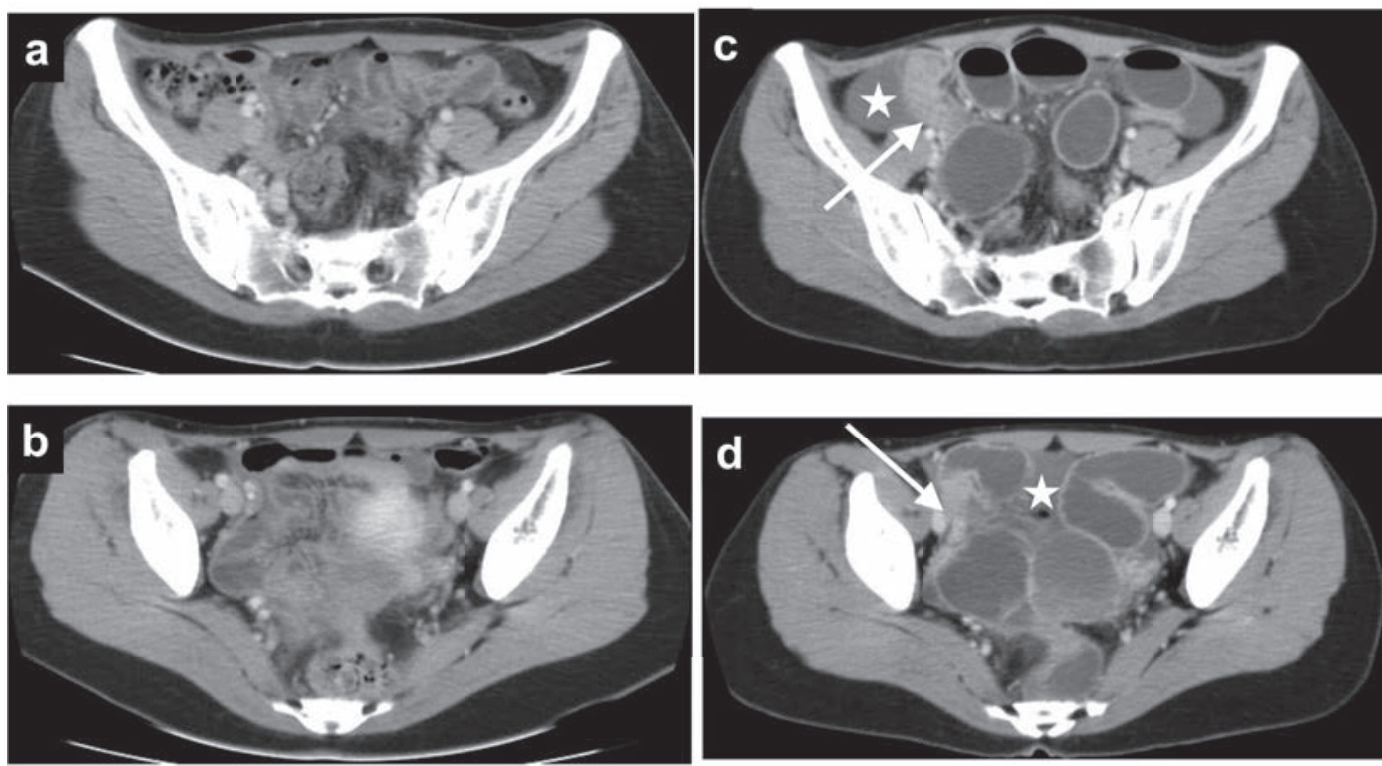

図 2 腹部CT（ $a, b$ : 月経34日目無症状時、 $c, d ：$ 月経 2 日目月経随伴性腸閉塞発症時）

$a, b$ : 腸管の浮腫や狭窄など腸管子宮内膜症を疑う所見は認めなかった。

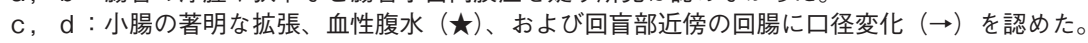


明な拡張、血性腹水、および回盲部近傍の回腸に 癒着による狭窄を疑う所見を認めた（図 $2 \mathrm{c}, \mathrm{d}$ )。 月経時に腸閉塞を繰り返したことと今回のCT所 見とを合わせて回腸子宮内膜症の存在を強く疑 い、外科と連携を図った。ここで、翌月に予定し ていた手術日が次回の月経と重なる可能性が高い ことが判明した。次回の月経時にも腸閉塞を発症 すれば手術が延期になる可能性や、拡張した腸管 により操作スペースが確保できず開腹手術への術 式変更の可能性などが危惧された。腸閉塞の再発 を予防できる可能性があると考えジエノゲスト内 服を開始した。腸閉塞を発症することなく1か月 後に予定手術を迎えた。手術前日までジエノゲス 卜内服を継続した。術前の腸管処置を外科の腸管 切除術に準じて施行し、外科と共同で腹腔鏡下に 病巣摘出術を行った。

術中所見: 婦人科医が経腟的にマニピュレーター
を子宮に留置した後、ダイヤモンド型にトロッカ 一を配置し、腹腔内の観察を行った。左卵巣は鷄 卵大に腫大しており、子宮後壁に直腸とともに強 く癒着していた。左卵管は左卵巣を巻くように強 固に癒着していた。右卵巣は正常大であったが、 子宮広間膜広葉にフィルム様に癒着していた。右 卵管も右卵巣を巻くようにフィルム様に癒着して いた。肉眼的には左右の卵管采に異常所見を認め なかった。ダグラス窩は一部閉鎖していた。 R-ASRM分類56点でIV期と診断した。最初に婦 人科医が癒着剥離を行い、左卵巣子宮内膜症性囊 胞を摘出した（図 $3 \mathrm{a}, \mathrm{b}$ )。両側卵管の色素通 過を確認した。回腸子宮内膜症を疑う結節を、バ ウヒン弁から $10 \mathrm{~cm}$ 口側と $15 \mathrm{~cm}$ 口側の 2 か所に 認めた。この 2 か所で回腸は癒着しており（図 4 a )、外科医と交代した。外科医が腹腔鏡下に盲 腸を後腹膜から授動し、12 cmの回腸を臍部の切

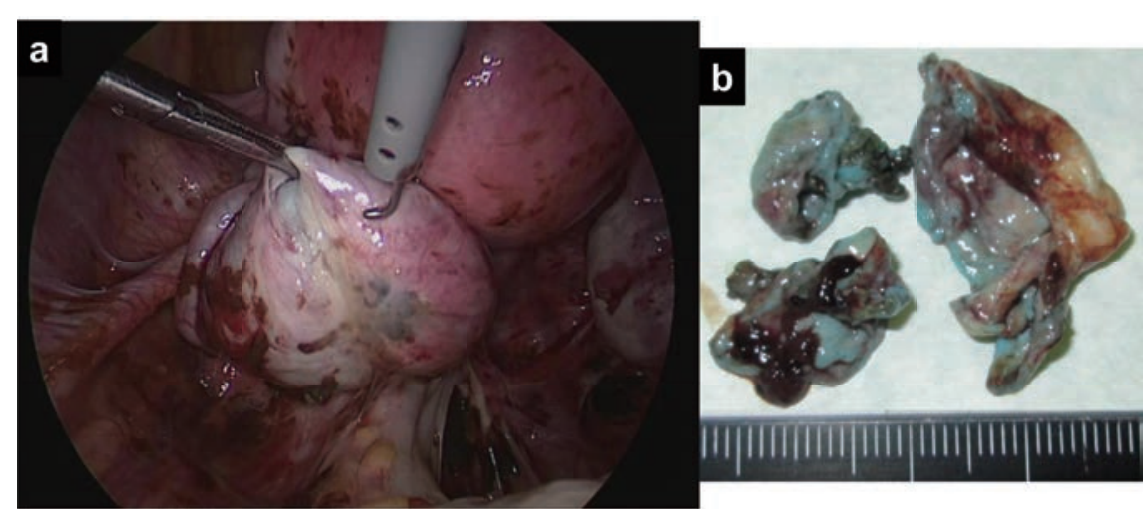

図3 術中所見 1

$\mathrm{a} ：$ 囊胞性に腫大した左卵巣。

$\mathrm{b}:$ 腹腔鏡下に摘出した囊胞（両側卵管の色素通過を確認したためインジゴカルミン液が付着している）。

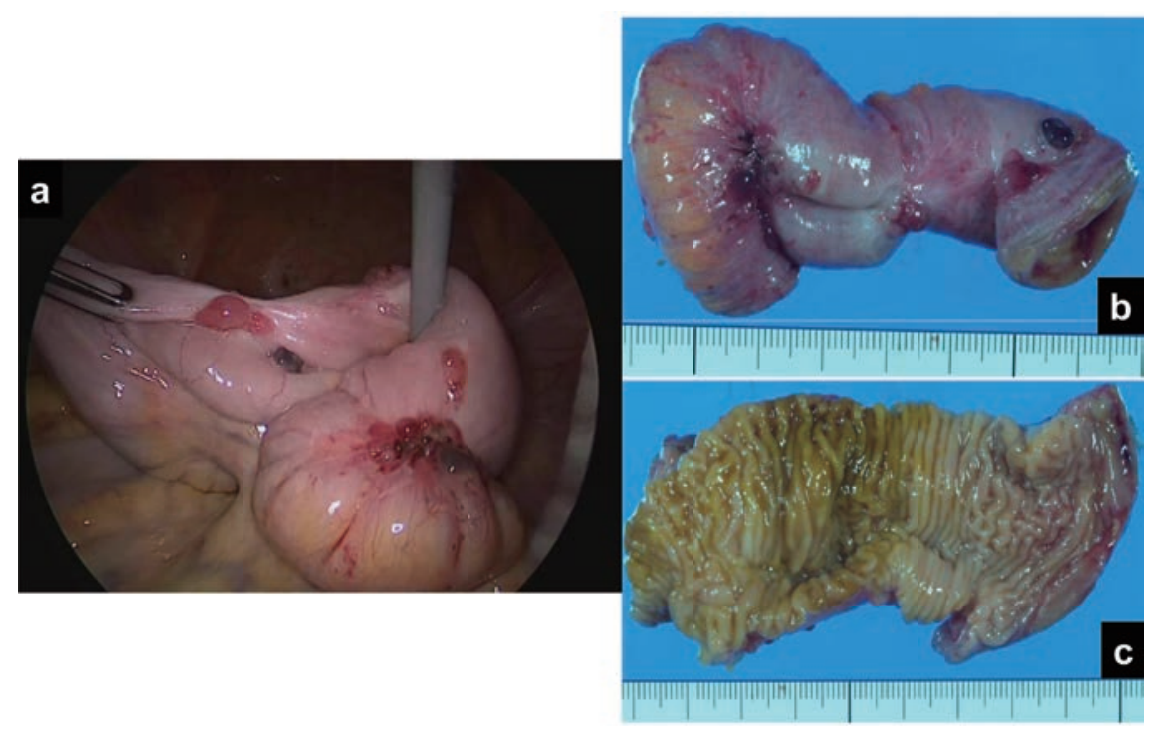

図 4 術中所見 2

a : 回腸遠位部 2 か所に内膜症性病変を疑う結節を認め、この 2 か所で回腸は癒着していた。

$\mathrm{b}$ ：腹腔鏡補助下（体外式）に切除した $12 \mathrm{~cm}$ 回腸。

c : 肉眼的に粘膜面には病変を認めなかった。 


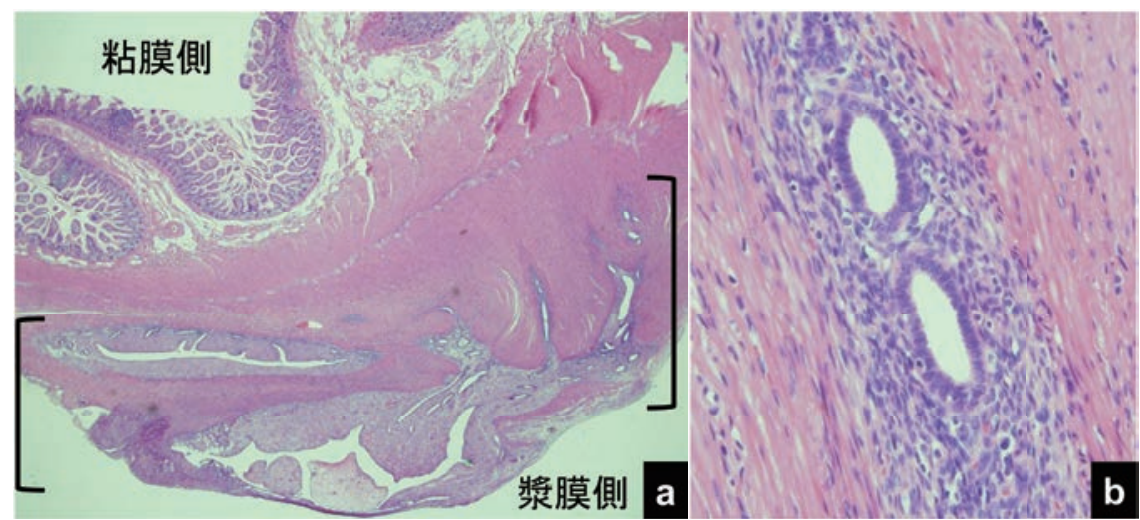

図 5 回腸切除検体の病理組織像 (HE染色、a : $\times 20 、 b: \times 400)$

漿膜から筋層にかけて子宮内膜類似の組織が散在していた（病変の範囲を［］で示した）。 粘膜には病変を認めなかった。

開創より体外式に部分切除した(図 4 b，c )。端々 吻合後、腹腔内に還納し、婦人科医と交代した。 婦人科医が腹腔内の止血確認を最終的に行い、閉 創して手術を終了した。手術時間は165分、出血 量は $15 \mathrm{mLであった。}$

術後病理組織検査: 回腸子宮内膜症（図 $5 \mathrm{a}, \mathrm{b}$ )、 左卵巣子宮内膜症性囊胞

術後経過：術後 1 日目から飲水を開始し、術後 4 日目から食事を開始した。術後経過は良好であり、 術後 6 日目に退院した。術後 1 日目からジエノゲ ス卜内服を再開した。産婦人科・外科ともに術後 の外来診察が完了するまでの 1 か月間内服を継続 した後、不妊治療を開始した。術後 1 年が経過し た現在まで合併症はなく不妊治療中である。卵巣 子宮内膜症性囊胞の再発や腸閉塞の再発は認めて いない。

\section{【考察】}

本症例の経験を通して以下の二点に留意すべき であるとわかった。第一点は、腸管子宮内膜症は 月経時に腸閉塞を繰り返すことがあるため、腹腔 鏡下手術を予定する際には月経期を外した方がよ いということである。本症例では当初予定した手 術日がちょうど月経と重なる見込みであった。月 経時に腸閉塞を発症すれば手術の延期や開腹手術 への術式変更の可能性が考えられた。腸閉塞に対 する腹腔鏡下手術の適応に関して一定の見解は得 られていないが、トロッカー挿入時の腸管損傷を 防ぐために術前の腸管減圧が必要で、操作スペー スの確保が可能な例において適応となり、減圧不 良例は避けるべきであると多くの報告 ${ }^{1-4)}$ で共通 している。本症例で手術予定日に月経随伴性腸閉 塞を発症していたら、イレウス管の挿入により腸
管減圧が必要であり十分な減圧が得られるまで手 術を延期せざるを得なかった可能性がある。また、 急性腹症に対する腹腔鏡下手術のレビュー ${ }^{5)}$ で は、急性の小腸閉塞に対する腹腔鏡下手術は難易 度が高いとされている。腸閉塞のため操作スペー スが減少し、拡張した腸管は脆弱でその扱いに細 心の注意が必要で、腸管の閉塞部位の同定が困難 な可能性があると指摘されている。European Association for Endoscopic surgeryの急性腹症全 般に対する腹腔鏡下手術のガイドライン ${ }^{6)}$ では、 小腸閉塞に対する腹腔鏡下手術は限られた症例に おいて可能である（推奨度C）と記載され、主な 懸念点は開腹移行率が高く、腹腔鏡下手術を完遂 できたのは50〜60\%にすぎないと述べられてい る。本症例で手術予定日に月経随伴性腸閉塞を発 症していたら、予定通り手術を開始できたとして も開腹移行となっていたか、あるいは外科との相 談の上で最初から開腹手術へ術式変更をしていた 可能性がある。月経随伴性の消化器症状を有する 女性の骨盤子宮内膜症手術の際には、腸管子宮内 膜症が存在する可能性も考慮して手術に臨む必要 がある。術前準備や手術体制を整えてプランニン グ通り腹腔鏡下手術を行うためには、腸管子宮内 膜症は月経時に腸閉塞を繰り返す可能性があるが 故に月経期以外に手術を予定する方がよいと考え られる。

本症例で示された第二点は、何らかの理由によ りやむを得ず手術日が月経期と重なる場合や月経 不順があり月経期が予想できない場合には、手術 日に腸閉塞とならないよう腸閉塞を予防できる可 能性がある薬物療法を行いつつ、腸閉塞を発症し た場合の手術の延期や開腹手術への術式変更の可 能性につき患者に説明を行っておく必要があると 
いうことである。腸閉塞子防のための術前薬物療 法の選択肢としては大建中湯や腸管子宮内膜症の 薬物治療同様低用量ピル、GnRHアゴニスト、ジ エノゲストが考えられる。本症例では予定手術ま での 1 か月間ジエノゲストを内服した。低用量ピ ルは血栓症の問題から周術期の内服は禁忌であ る。GnRHアゴニストは初回投与後のフレアアッ プがあり1か月では効果が得られるか疑問があっ た。ジエノゲストについては、亜イレウスを発症 した症例にジエノゲストを投与し亜イレウスを起 こさなくなったという報告 ${ }^{7)}$ があるが、それ以外 に腸管子宮内膜症による腸閉塞発症予防に有効と いう報告はなかった。これは腸閉塞など明らかな 器質的障害を伴う症例は初めから外科的治療の適 応とする報告 ${ }^{8.9)}$ が多く、腸管子宮内膜症による 腸閉塞発症予防にジエノゲストが試される機会が ほとんどないからであると推察される。

腸管子宮内膜症による月経随伴性腸閉塞の発症 機序は、病状の進行に伴って癒着による狭窄など の器質的な変化を腸管に引き起こした上に、それ が腸管筋層内に存在する内膜症組織での出血や炎 症性浮腫などにより月経時に増悪するためと考え られる ${ }^{8)}$ 。そのことに加えて、月経時に子宮内膜 および内膜症組織より産生されるプロスタグラン ジンが腸管蠕動を充進させ、狭窄部位を通過しよ うとする腸管内容物が月経時は相対的に増加する ため通過障害となり、月経時に繰り返す腸閉塞を 発症するのではないかと考えている。したがって、 プロスタグランジン $\mathrm{E}_{2}$ などの産生を抑制し抗炎症 作用を示す ${ }^{10,11)}$ ジエノゲストは、この月経随伴性 腸閉塞の発症機序を考えると腸管子宮内膜症組織 での炎症を抑え、プロスタグランジン産生を抑制 乙腸管蠕動の充進を起こさず月経随伴性腸閉塞発 症に抑制的に働くと考えられる。本症例において は術前の 1 か月間と短期間の内服ではあったが、 腸閉塞を再発することなく予定手術を迎えること ができた。偶然であった可能性は否定しきれない が、前述のジエノゲストを投与し亜イレウスを起 こさなくなったという報告 ${ }^{7}$ 、月経随伴性腸閉塞 の発症機序、およびジエノゲストの卵巣機能抑制 による月経抑止作用と抗炎症作用を考えると、ジ エノゲストが腸閉塞発症子防に有効であった可能 性も十分にある。今後の症例数の集積と長期間の 観察が必要である。

本症例の場合の卵巣子宮内膜症性囊胞および回 腸子宮内膜症に対する治療方針につき考察する。 $4 \mathrm{~cm}$ 大の左卵巣子宮内膜症性囊胞については、
挙児希望があり一般不妊治療で妊娠に至らなかっ たこと、強い月経痛があったことから腹腔鏡下囊 胞摘出術適応と考えた。子宮内膜症取扱い規約 ${ }^{12)}$ の不妊症に対するガイドラインでは、 $3 \sim 4 \mathrm{~cm}$ 以上の卵巣チョコレート囊胞が存在する場合には 手術療法を原則とすることが推奨されている。卵 巣チョコレート囊胞に対する手術療法は産婦人科 内視鏡手術ガイドライン ${ }^{13)}$ で腹腔鏡下手術が推 奨されており、開腹手術と比べて手術侵襲の点で 腹腔鏡下手術が優れていると記載されている。ヨ ーロッパ生殖医学会ガイドライン ${ }^{14)}$ では、中等 度から重症の子宮内膜症の場合手術療法と待機療 法に関するcontrolled studyはまだないが、3つ の前向きコホート研究の結果から術後に自然妊娠 率を向上させるという点で腹腔鏡下手術は考慮で きるとされている。不妊症患者に対して囊胞摘出 術を行った場合卵巣機能の低下が懸念されるが、 本症例の術前 $\mathrm{AMH} 3.73 \mathrm{ng} / \mathrm{mL}$ という值は卵巣 予備能が年齢平均值程度であることを示してお り、卵巣予備能が極度に低い症例ではないことを 術前に確認していた。これらのことに加えて、病 巣は片側性であり片側の囊胞摘出を行っても術後 の卵巣機能の消失は避けられると判断し、腹腔鏡 下囊胞摘出術を施行した。

本症例の回腸子宮内膜症に対する治療方針につ いては、術中所見で器質的疾患である回腸子宮内 膜症による癒着、狭窄が強く疑われ、これが月経 時に繰り返す腸閉塞の原因と考えられたこと、挙 児希望があり術後に不妊治療を開始する予定であ ったため、薬物治療が選択しづらかったこと、こ れらの 2 点から回腸部分切除術の適応であると判 断した。本症例では回腸部分切除術を腹腔鏡補助 下に行った。腸管子宮内膜症に対する腹腔鏡下手 術と開腹手術に関する大規模なcontrolled study は存在しないが、大腸子宮内膜症に対する大腸切 除術を腹腔鏡補助下手術群と開腹手術群に割り付 けたランダム化比較試験の報告 ${ }^{15,16)}$ がある。観察 期間の中央值19か月の短期成績の報告 ${ }^{15)}$ では、 開腹と比較して腹腔鏡補助下では出血量が少な く、合併症が少なく、高い妊娠率が得られ累積妊 娠率は60\%であった。開腹手術群は妊娠に至らな かった。症状やQOLの改善は両群同等であった。 観察期間中央值51か月の長期成績の報告 ${ }^{16)}$ では、 両群ともに大腸子宮内膜症の再発は認めず、症状 やQOLの改善、妊娠率に差はなかったが、自然 妊娠に至ったのは腹腔鏡補助下手術群だけであっ た。大腸子宮内膜症に対する開腹の大腸切除術は 
腹臆鏡下手術が禁忌な症例に限るべきであると結 論付けられている。本症例のように不妊症があり 腸閉塞を反復している腸管子宮内膜症患者の場合 には、QOLの向上に加え手術後の妊娠率向上に 寄与する可能性もあり、腹腔鏡下に扔ける積極的 な病巣除去術も選択肢と考えられる。

本症例の術後は不妊治療を開始するまでの 1 か 月間ジエノゲストを内服した。卵巣子宮内膜症性 囊胞摘出術後の再発率は 2 年で $21.5 \% 、 5$ 年で 40 〜 50\%に達する ${ }^{17)}$ ため、挙児を希望するまで継続 的な薬物治療が再発予防に強く推奨されている ${ }^{18)}$ 。 腸管子宮内膜症術後の再発率は 2 年以上経過観察 した症例で4.7〜25\%と報告されており ${ }^{19)}$ 、卵巣子 宮内膜症性囊胞同様に腸管子宮内膜症についても 術後の再発予防のための薬物治療が重要と考えら れる ${ }^{18)}$ 。薬物治療として低用量ピルが卵巣子宮内 膜症性囊胞術後の再発リスクの低減に有効である ことが示されている ${ }^{20)}$ 。しかし低用量ピルは周術 期には投与禁忌である。卵巣子宮内膜症性囊胞摘 出術後 4 か月で $5 \mathrm{~cm}$ 大の囊胞再発を認めた早期

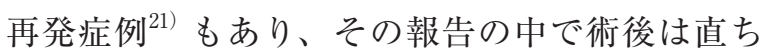
に薬物治療を開始するべきであると述べられてい る。ジエノゲストは低用量ピルと異なり血栓症の 懸念が少なく周術期にも投与可能であり、卵巣子 宮内膜症性囊胞術後再発予防効果に関して低用量 ピルと有意差はないとの報告22,23) もある。したが って、短期間で再発する症例もあるため術後早期 に薬物治療を開始し、挙児を希望するまで継続す ることが子宮内膜症術後の再発予防に重要である と考えられる。本症例の場合は挙児希望があり術 後不妊治療を開始する予定であった。術後 1 日目 からジエノゲスト内服を再開し、産婦人科・外科 ともに術後の外来診察が完了するまでの 1 か月間 内服を継続した後、不妊治療を開始した。今回 1 か月間行ったジエノゲストの術後投与が不妊治療 期間までの再発予防にどの程度寄与したかは不明 であるが、一般的に術後早期に妊娠を成立させる か、あるいは不妊治療の中断など妊娠を目指さな い期間がある場合には内分泌療法など何らかの方 策を講じることを検討し、途切れなく管理するこ とが本症例のような回腸子宮内膜症を伴う子宮内 膜症合併不妊症例の術後再発予防と妊孕性保持の ために重要であると考えられる。

\section{【結論】}

術前に腸管子宮内膜症の存在を疑って十分な準 備を行うことにより、腸管切除を考慮した体制で
腹腔鏡下手術を施行し、回腸子宮内膜症と左卵巣 子宮内膜症性囊胞を一期的に切除しえた。月経随 伴性の消化器症状を有する女性の骨盤子宮内膜症 手術の際には、腸管子宮内膜症が存在する可能性 も念頭に置き、必要ならば腸管切除も行うことが できるように術前準備や手術体制を整えて手術に 臨むことが重要である。そのような万全の態勢で 腹腔鏡下手術を行うためには、腸管子宮内膜症は 月経時に腸閉塞を繰り返す可能性があるが故に月 経期以外に手術を予定する方がよい、ということ が本症例の経験からわかった。やむを得ない場合 には、予定手術を迎えるまで腸閉塞の発症を予防 できる可能性がある薬物療法を行いつつ、腸閉塞 を発症した場合の手術の延期や開腹手術への術式 変更の可能性につき患者に説明を行っておく必要 があると考えられた。

本論文の要旨は第 55 回日本産科婦人科内視鏡学 会学術講演会において発表した。

謝辞

本症例の診療に多大なる御協力を賜りました豊 橋市民病院 一般外科 三竹泰弘先生、青葉太郎先 生、同 病理診断科 前多松喜先生に深謝致します。

\section{【文献】}

1）木下水信、他：腸管癒着に対する腹腔鏡を用いた低 侵襲手術. 日腹部救急医会誌2006; 26: 31-36.

2) 西山徹、竹林徹郎、那須裕也：イレゥスに対する腹 胿鏡（補助）下手術. 日腹部救急医会誌2008; 28: 2127.

3) 松本浩次、他：当院に扔ける腸閉塞例に対する腹腔 鏡下手術症例の検討. 日内視鏡外会誌2012; 17: 461466.

4）野澤雅之、他：当院における腹部救急疾患に対する 腹腔鏡下手術の検討. 日腹部救急医会誌2014; 34: 935-939.

$5)$ Benoit Navez, Julie Navez: Laparoscopy in the acute abdomen. Best Pract Res Clin Gastroenterol 2014; 28: 3-17.

6 ) Ferdinando Agresta, et al.: Laparoscopic approach to acute abdomen from the Consensus Development Conference of the Società Italiana di Chirurgia Endoscopica e nuove tecnologie (SICE), Associazione Chirurghi Ospedalieri Italiani (ACOI), Società Italiana di Chirurgia (SIC), Società Italiana di Chirurgia d'Urgenza e del Trauma (SICUT), Società Italiana di Chirurgia nell'Ospedalità Privata (SICOP), and the European Association for Endoscopic 
Surgery (EAES). Surg Endosc 2012; 26: 2134-2164.

7 ）山口昌俊、他：腸管に発生し、通過障害をきたした 子宮内膜症の3例．日エンドメトリオーシス会誌2013; 34: 189-191.

8 ）奥久人、他：月経時に増悪しイレウスを併発した回 盲部子宮内膜症の 1 例 - 外科と婦人科の連携による腹 腔鏡補助下回盲部切除術より一。 日エンドメトリオ ーシス会誌2009; 30: 74-77.

9 ) 山本誠士、他：腸閉塞で発見されたリンパ節病変を 伴う回盲部子宮内膜症の1例. 日臨外会誌 $2012 ; 73$ : 2973-2977.

10) Yutaka Shimizu, et al.: Dienogest, a synthetic progestin, inhibits prostaglandin $\mathrm{E}_{2}$ production and aromatase expression by human endometrial epithelial cells in a spheroid culture system. Steroids 2011; 76: 60-67.

11) Giovanni Grandi, et al.: Does dienogest influence the inflammatory response of endometriotic cells? A systematic review. Inflamm Res 2016; 65: 183-192.

12）日本産科婦人科学会編：治療のガイドライン、子宮 内膜症取扱い規約 第2 部 治療編 - 診療編、2010; 53-64、金原出版.

13）日本産科婦人科内視鏡学会編：第4章子宮内膜症、産 婦人科内視鏡手術ガイドライン 2013年版、2013; 5569、金原出版.

14) G. A. J. Dunselman, et al.: ESHRE guideline: management of women with endometriosis. Hum Reprod 2014; 29: 400-412.

15) Emile Daraï, et al.: Randomized trial of laparoscopically assisted versus open colorectal resection for endometriosis: morbidity, symptoms, quality of life, and fertility. Ann Surg 2010; 251: 1018-1023.

16) Cyril Touboul, et al.: Long-term symptoms, quality of life, and fertility after colorectal resection for endometriosis: extended analysis of a randomized controlled trial comparing laparoscopically assisted to open surgery. Surg Endosc 2015; 29: 1879-1887.

17) Sun-Wei Guo: Recurrence of endometriosis and its control. Hum Reprod Update 2009; 15: 441-461.

18) Kaori Koga, et al.: Prevention of the recurrence of symptom and lesions after conservative surgery for endometriosis. Fertil Steril 2015; 104: 793-801.

19) Christel Meuleman, et al:: Surgical treatment of deeply infiltrating endometriosis with colorectal involvement. Hum Reprod Update 2011; 17: 311-326.

20) Paolo Vercellini, et al.: Long-term adjuvant therapy for the prevention of postoperative endometrioma recurrence: a systematic review and meta-analysis. Acta Obstet Gynecol Scand 2013; 92: 8-16.

21）鈴木絢子、他：術後早期に再発した子宮内膜症性囊 胞の一例. 日産婦内視鏡会誌2013; 29: 195-200.

22）太田啓明、他：子宮内膜症術後の再発を防ぐために - 系統的深部子宮内膜症切除と術後薬物療法一。 日
エンドメトリオーシス会誌2012; 33: 122-127.

23）重見大介、他：子宮内膜症の術後再発予防における ジエノゲストの効果. 日エンドメトリオーシス会誌 2013; 34: 154-156. 